\title{
Evaluation of the impact of six different DNA extraction methods for the representation of the microbial community associated with human chronic wound infections using a gel-based DNA profiling method
}

\author{
Ayomi Dilhari ${ }^{1}$, Asanga Sampath', Chinthika Gunasekara ${ }^{1}$, Neluka Fernando ${ }^{1}$, Deepaka Weerasekara²,
} Chris Sissons $^{3}$, Andrew McBain ${ }^{4}$ and Manjula Weerasekera ${ }^{1 *}$

\begin{abstract}
Infected chronic wounds are polymicrobial in nature which include a diverse group of aerobic and anaerobic microorganisms. Majority of these communal microorganisms are difficult to grow in vitro. DNA fingerprinting methods such as polymerase chain reaction-denaturation gradient gel electrophoresis (PCR-DGGE) facilitate the microbial profiling of complex ecosystems including infected chronic wounds. Six different DNA extraction methods were compared for profiling of the microbial community associated with chronic wound infections using PCR-DGGE. Tissue debris obtained from chronic wound ulcers of ten patients were used for DNA extraction. Total nucleic acid was extracted from each specimen using six DNA extraction methods. The yield, purity and quality of DNA was measured and used for PCR amplification targeting V2-V3 region of eubacterial 16S rRNA gene. QIAGEN DNeasy Blood and Tissue Kit ( $K$ method) produced good quality genomic DNA compared to the other five DNA extraction methods and gave a broad diversity of bacterial communities in chronic wounds. Among the five conventional methods, bead beater/ phenol-chloroform based DNA extraction method with STES buffer (BP1 method) gave a yield of DNA with a high purity and resulted in a higher DGGE band diversity. Although DNA extraction using heat and $\mathrm{NaOH}$ had the lowest purity, DGGE revealed a higher bacterial diversity. The findings suggest that the quality and the yield of genomic DNA are influenced by the DNA extraction protocol, thus a method should be carefully selected in profiling a complex microbial community.
\end{abstract}

Keywords: DNA extraction methods, Polymerase chain reaction-denaturing gradient gel electrophoresis (PCRDGGE), Wound infection

\section{Introduction}

Microorganisms associated with polymicrobial infections such as chronic wound infections are diverse and often unculturable (Han et al. 2011; Oates et al. 2012; Wadinamby 2013). Molecular biological methods based on $16 \mathrm{~S}$ rDNA and other genetic markers have been used

\footnotetext{
*Correspondence: mmweera@yahoo.com; mmweera@sjp.ac.lk ${ }^{1}$ Department of Microbiology, Faculty of Medical Sciences, University of Sri Jayewardenepura, Gangodawila, Nugegoda, Sri Lanka Full list of author information is available at the end of the article
}

effectively to analyze diversity of microbial populations in environmental samples (Nakatsu 2007; Øvreås et al. 1997) as well as clinical specimens (Ariefdjohan et al. 2010; Oates et al. 2012; Walter et al. 2001). Molecular methods can bypass the culture isolation and can generate a comprehensive and precise set of data which is important to understand the role of these microorganisms in polymicrobial infections (Oates et al. 2012; Tannock 2002). As a molecular fingerprinting technique, polymerase chain reaction-denaturing gradient 
gel electrophoresis (PCR-DGGE) has been successfully applied to profile diverse microbial communities of various clinical specimens (Ariefdjohan et al. 2010; Oates et al. 2012; Walter et al. 2001; Weerasekera et al. 2017, 2013).

Extracting DNA from complex microbial communities is a challenge. The analytical success of molecular techniques is greatly affected by its reliance on the efficient cell lysis and the quality of the recovered DNA (Ariefdjohan et al. 2010; De Lipthay et al. 2004; McOrist et al. 2002). (De Lipthay et al. 2004; Moore et al. 2008). Successful extraction of DNA involves effective disruption of cells, denaturation of proteins and nucleoprotein complexes, inactivation of nucleases such as DNases and recovery of the DNA. The extracted DNA should have low contamination of proteins, carbohydrates, lipids and RNAs. The choice of the extraction method should be based on the required molecular weight of the target DNA, required quantity, purity, extraction time and cost (Ariefdjohan et al. 2010). Quality and integrity of the isolated nucleic acids will directly affect the results of the experiment. The goal of this study was to compare the relative efficacy of five conventional DNA extraction methods and one commercial kit in extracting bacterial genomic DNA from infected tissues of chronic wound specimens. Although these extraction methods have been separately reported for DNA extraction from several biological specimens (Ariefdjohan et al. 2010; Oates et al. 2012; Walter et al. 2001), our study further extends this knowledge by a direct comparison of these methods and application of the extracted DNA to PCR-DGGE technique. Further we aimed to identify the optimized DNA extraction conditions to obtain a high and pure DNA yield from chronic wound specimens in order to effectively profile bacterial communities using PCR-DGGE.

\section{Materials and methods Ethical statement}

The study was granted ethical approval from Ethics Review Committee of University of Sri Jayewardenepura (Ref. No: 12/16) and Colombo South Teaching Hospital (Ref. No: 506) in Sri Lanka.

\section{Specimen collection and preparation}

Wound tissue debridement specimens from chronic foot wounds were collected from ten patients undergoing surgical debridement at a Tertiary Care Hospital in Sri Lanka. The specimens were collected by a well-trained and qualified medical officer/surgeon after obtaining the informed consent from the patients.

The tissue debridement specimens were collected into sterile eppendorf tubes and immediately transported in a portable cooler and stored at $-20{ }^{\circ} \mathrm{C}$ for a few weeks or $-80{ }^{\circ} \mathrm{C}$ up to several months. The samples from each patient were kept separate and were not pooled. Each tissue debridement specimen was weighed and cut into 12 small pieces (each weighing $25 \mathrm{mg}$ ) using a sterile scalpel or a sharp sterile needle.

Twenty-five milligrams of tissue debridement specimen was subjected to each DNA extraction method. Each extraction was done in duplicate. The methods $\mathrm{H} 1$ and $\mathrm{H} 2$ involved heat treatment of tissue specimens (Asadzaheh et al. 2010; Sampath et al. 2016; Silva et al. 2012), BP1 and BP2 were based on bead beater-phenol chloroform extraction (Sampath et al. 2016; Walter et al. 2001; Weerasekera et al. 2013); method S was based on DNA precipitation at high salt concentration (Asadzaheh et al. 2010) and method K used a commercial DNA extraction kit (Oates et al. 2012).

\section{Heating in distilled water inside a boiling water bath $(\mathrm{H} 1$ method)}

In the procedure of heat treatment in Distilled water (H1 method), the weighed tissue debridement sample was thoroughly minced and suspended in $100 \mu \mathrm{l}$ of sterile distilled water. The specimen was immersed for $10 \mathrm{~min}$ in a $100{ }^{\circ} \mathrm{C}$ water bath. Tubes were centrifuged at $(13,000 \mathrm{rpm}) 15,493 \times \mathrm{g}$ for $10 \mathrm{~min}$ and the supernatant was removed to a sterile tube and stored at $-20{ }^{\circ} \mathrm{C}$. This method was carried out as described by Silva et al. in 2012 with modifications (Silva et al. 2012).

\section{Heating in $\mathrm{NaOH}$ inside a boiling water bath ( $\mathrm{H} 2$ method)}

DNA extraction using the heat treatment in $\mathrm{NaOH}(\mathrm{H} 2$ method) was carried out as described by Asadzaheh et al. (2010) with the modifications (Asadzaheh et al. 2010). Tissue debridement specimen was minced, suspended in $100 \mu \mathrm{l}$ of $50 \mathrm{mM} \mathrm{NaOH}$ and incubated in a $100{ }^{\circ} \mathrm{C}$ water bath for $20 \mathrm{~min}$. Subsequently $20 \mu \mathrm{l}$ Tri- $\mathrm{HCl}(\mathrm{pH}=7.5)$ was added. The tube was gently mixed by inverting several times and centrifuged at $(13,000 \mathrm{rpm}) 15,493 \times \mathrm{g}$ for $10 \mathrm{~min}$. The upper aqueous phase was transferred into a sterile clean tube and stored at $-20^{\circ} \mathrm{C}$ until used.

\section{Bead beater-phenol chloroform extraction method using STES buffer (BP1 Method)}

Bead beater-phenol chloroform extraction method using STES buffer (BP1 method) was carried out according to the procedure described by Sampath et al. in 2016 (Sampath et al. 2016). A tissue debridement specimen was suspended in $100 \mu \mathrm{l}$ STES buffer [ $200 \mathrm{mM}$ Tris $\mathrm{HCl}(\mathrm{pH}$ 7.6), $100 \mathrm{mM}$ EDTA, $0.1 \% \mathrm{SDS}$ ] and $40 \mu \mathrm{l}$ of TE buffer [ $10 \mathrm{mM}$ Tris $\mathrm{HCl}$ (pH 8), $1 \mathrm{mM}$ EDTA]. Further, $120 \mu \mathrm{l}$ Phenol: Chloroform mixture $(1: 1 \mathrm{~V} / \mathrm{V})$ and $0.3 \mathrm{~g}$ sterile zirconium beads $(0.1 \mathrm{~mm}$ diameter; Bio Spec-Products) were added to each tube. Then the specimens were homogenized 
using a mini bead beater (model 3110BX; Bio Spec Products) at $480 \mathrm{rpm}$ for $5 \mathrm{~min}$. The upper aqueous phase $(100 \mu \mathrm{l})$ was transferred to a sterile eppendorf tube. Ten microliter of $3 \mathrm{M}$ sodium acetate was added and DNA was precipitated in the presence of $220 \mu \mathrm{l}$ cold ethanol $(100 \%)$ at $-20^{\circ} \mathrm{C}$ for $4 \mathrm{~h}$. The solution was then subjected for centrifugation at $(13,000 \mathrm{rpm}) 15,493 \times \mathrm{g}$ for $12 \mathrm{~min}$. Air dried DNA pellet was dissolved in $30 \mu \mathrm{l}$ TE buffer and stored at $-20{ }^{\circ} \mathrm{C}$ until used.

\section{Bead beater-phenol chloroform extraction method using TN150 buffer (BP2 method)}

The process of bead beater-phenol chloroform extraction method using TN150 buffer (BP2 method) was carried out according to the procedure described by Walter et al. (2001) with modifications (Walter et al. 2001). The weighed tissue debridement specimen was suspended in $1 \mathrm{ml}$ of sterile TN150 buffer and $0.3 \mathrm{~g}$ of sterile zirconium beads (diameter, $0.1 \mathrm{~mm}$ ) were added. The tube was placed in a mini-bead beater (model 3110BX; Bio Spec Products), shaken at $480 \mathrm{rpm}$ for $3 \mathrm{~min}$, and stored on ice. It was subjected for centrifugation at $(13,000 \mathrm{rpm})$ $15,493 \times g$ for $5 \mathrm{~min}$. The upper phase $(300 \mu \mathrm{l})$ was transferred into a new sterile eppendorf tube. Two hundred microliters of saturated phenol and $200 \mu \mathrm{l}$ of chloroformisomyl alcohol (24:1) were then added. The tube was inverted several times and centrifuged at (13,000 rpm) $15,493 \times g$ for $12 \mathrm{~min}$. The supernatant was transferred into a sterile new micro-centrifuge tube. Fifty microliters of $3 \mathrm{M}$ sodium acetate and $1 \mathrm{ml}$ ice cold ethanol was added to the tube, mixed by inverting and stored at $-20{ }^{\circ} \mathrm{C}$ for $4 \mathrm{~h}$ for precipitation of DNA. Following centrifugation at $(13,000 \mathrm{rpm}) 15,493 \times g$ for $12 \mathrm{~min}$, supernatant was discarded and the DNA pellet was allowed to air dry. After all the traces of alcohol had evaporated, DNA was dissolved in $30 \mu \mathrm{l}$ of sterile TE buffer [10 mM Tris $\mathrm{HCl}\left(\mathrm{pH}\right.$ 8), $1 \mathrm{mM}$ EDTA] and stored at $-20^{\circ} \mathrm{C}$ until used.

\section{Salting out method (S method)}

Salting out method (S method) was performed according to the procedure described by Asadzaheh et al. (2010) with several modifications (Asadzaheh et al. 2010). The weighed tissue debridement sample was suspended in $600 \mu \mathrm{l}$ of sterile TNES buffer $[10 \mathrm{mM}$ Tris $-\mathrm{HCl} \mathrm{pH}=7.5$, $400 \mathrm{mM} \mathrm{NaCl}, 100 \mathrm{mM}$ EDTA, $0.5 \% \mathrm{SDS}$ ] and $20 \mu \mathrm{l}$ of proteinase $\mathrm{K}$ and mixed by inverting. The mixture was thoroughly mixed by vortex mixing and incubated at $50{ }^{\circ} \mathrm{C}$ inside a water bath until the tissue was completely lysed. After tissue debris was completely lysed, $200 \mu \mathrm{l}$ $5 \mathrm{M} \mathrm{NaCl}$ was added and mixed vigorously for $20 \mathrm{~s}$. The tube was centrifuged at $(13,000 \mathrm{rpm}) 15,493 \times \mathrm{g}$ for $10 \mathrm{~min}$ and the supernatant was removed into a new sterile eppendorf tube. Equal volume of cold $100 \%$ ethanol was added, mixed, and kept overnight at $-20{ }^{\circ} \mathrm{C}$. The supernatant was discarded, after centrifugation at $(13,000 \mathrm{rpm}) 15,493 \times g$ for $12 \mathrm{~min}$. The pellet was washed sequentially using $500 \mu \mathrm{l}$ of $100 \%$ ethanol, $70 \%$ ethanol and allowed to air dry. The DNA was re-suspended with $30 \mu \mathrm{l} \mathrm{TE}$ buffer and stored at $-20^{\circ} \mathrm{C}$ until used.

\section{DNeasy blood and tissue kit (K method)}

The DNA extraction using the DNeasy blood and tissue kit [Qiagen Ltd., West Sussex, United Kingdom] (K method) was carried out following the manufactures' instructions. The weighed tissue debridement sample was dissected into small pieces and placed in a $1.5 \mathrm{ml}$ microcentrifuge tube. The dissected pieces of tissues were suspended in $180 \mu \mathrm{l}$ of buffer ALT and $20 \mu \mathrm{l}$ proteinase K. The mixture was thoroughly mixed by vortex mixing and incubated at $56{ }^{\circ} \mathrm{C}$ until the tissue was completely lysed. Following vortex mixing for $5 \mathrm{~min}$, buffer AL $(200 \mu \mathrm{l})$ was added to the sample and mixed. Two hundred microliter of ethanol was added. Mixture was pipetted into the DNeasy Mini Spin column placed inside a $2 \mathrm{ml}$ collection tube and centrifuged at $(8000 \mathrm{rpm}) 5875 \times g$ for $1 \mathrm{~min}$. The DNeasy Mini Spin column was then placed in a new collection tube and $500 \mu \mathrm{l}$ of buffer, AW1 was added and centrifuged. This step was repeated with the buffer AW2 and a high spin was given to dry the column membrane. The DNeasy Mini Spin column was subsequently placed in a clean micro-centrifuge tube and $100 \mu \mathrm{l}$ of buffer $\mathrm{AE}$ was added directly onto the membrane. Following centrifugation, DNA was eluted and stored at $-20{ }^{\circ} \mathrm{C}$ until used.

\section{DNA quantification}

DNA yield and DNA purity were determined using Nano drop 2000/200C spectrophotometer (Thermo Fisher Scientific, USA). The absorbance ratios; A260/280 nm and A260/230 nm were measured to assess DNA purity: A260/280 $\mathrm{nm}$ for protein contamination and A260/230 nm for salt and phenol contamination. DNA is known to absorb light at $260 \mathrm{~nm}$ and the A260/280 ratio; $1.8-2.0$ and A260/230 ratio; $>1.8$ indicating that the sample was of good purity with little or no contamination (Vesty et al. 2017).

\section{PCR amplification of bacterial DNA}

The V2-V3 region of the bacterial $16 \mathrm{~S}$ ribosomal DNA (rDNA) was PCR amplified using previously published universal eubacterium-specific primers HDA1 (with additional GC clamp) (5'CGC CCG GGG CGC GCC CCG GGC GGG GCG GGG GCA CGG GGG GAC TCC TAC GGG AGG CAG CAG T 3') (Forward primer) and HDA2 (5' GTA TTA CCG CGG CTG CTG 
GCA C 3') (Reverse primer) (Anukam and Reid 2007; Oates et al. 2012; Walter et al. 2001). This primer amplifies a DNA fragment having the nucleotide position between 339 and 539 (E. coli 16S rRNA gene). The GCclamp, which is a sequence that is rich in guanine and cytosine, is added to the $5^{\prime}$ end of the forward primer in order to prevent DNA from being completely denatured into single strands and to improve band resolution in denaturing gels.

Amplification reactions were performed in $200 \mu \mathrm{l}$ thin wall $\mathrm{PCR}^{\circledR}$ tubes (BIOLOGIX, USA). For direct PCR reactions using HDA 1 (GC clamped) and HDA 2 primers, $50.0 \mu \mathrm{l}$ reaction mixture consisted of $5.0 \mu \mathrm{l}$ of $10 \times$ PCR buffer containing $25 \mathrm{mmol} / \mathrm{l} \mathrm{MgCl}_{2}$ (Promega, USA); $1.0 \mu \mathrm{l}$ of $10 \mathrm{mM}$ dNTPs containing dATP, dGTP, dCTP and dTTP (Promega, USA); $1.0 \mu \mathrm{l}$ of each primer [10 mM] (IDT, USA); $0.25 \mu \mathrm{l}$ of Go Taq DNA polymerase (Promega, USA).

PCR amplification was done using GeneAmp PCR systems 9700 (Applied Bio systems). PCR reaction consisted of initial denaturation at $94{ }^{\circ} \mathrm{C}$ for $1 \mathrm{~min}$, followed by 30 cycles consisting of $94{ }^{\circ} \mathrm{C}$ for $30 \mathrm{~s}$ for denaturation, $56{ }^{\circ} \mathrm{C}$ for $30 \mathrm{~s}$ for annealing and $72{ }^{\circ} \mathrm{C}$ for $30 \mathrm{~s}$ for extension, a final extension at $68{ }^{\circ} \mathrm{C}$ for 7 min with final hold at $4{ }^{\circ} \mathrm{C}$. All PCR experiments included a negative (no template) control and a positive control. Resulting PCR products were separated by electrophoresis using $1 \times$ TAE $[40 \mathrm{mM}$ Tris $\mathrm{HCl}(\mathrm{pH} 8), 20 \mathrm{mM}$ acetic acid, $1 \mathrm{mM}$ EDTA] on a $1.5 \%(\mathrm{w} / \mathrm{v})$ agarose gel, stained with ethidium bromide and viewed by UV trans-illuminator [Vilber Lourmat, QUANTUM ST4].

\section{Denaturant gradient gel electrophoresis}

Denaturant gradient gel electrophoresis of amplified PCR products which were generated from DNA extracted from wound tissue debridement samples were performed on acrylamide gels in a DCode ${ }^{\mathrm{TM}}$ universal mutation detection system (Bio-Rad) according to the conditions described by Rasiah et al. (2005). The gels were prepared using $8 \%$ acrylamide (acrylamide to bis-acrylamide, $37.5: 1$ ) with a $30-55 \%$ gradient of urea and formamide. The gels were run using $1 \mathrm{x}$ TAE buffer $[40 \mathrm{mM}$ Tris $\mathrm{HCl}$ (pH 8), $20 \mathrm{mM}$ acetic acid, $1 \mathrm{mM}$ EDTA] at a constant voltage of $130 \mathrm{~V}$ at $60^{\circ} \mathrm{C}$ for $4 \mathrm{~h}$. Electrophoresis buffer $(1 \times \mathrm{TAE})$ was maintained throughout at $60^{\circ} \mathrm{C}$. Gels were stained with ethidium bromide, visualized and photographed on a UV trans-illuminator (Vilber Lourmat, QUANTUM ST4).

\section{Statistical analysis}

All extractions were performed in duplicate to account for analytical variability. Means of DNA yield were analyzed using SPSS (version 20.0; Inc. Chicago) by one-way ANOVA with Welch correction. Data were expressed as mean $\pm \mathrm{SD}$. The extraction methods which have a significant difference between its mean values were grouped and multiple comparison was done using the GamesHowell. Differences were considered as significant when $\mathrm{p}$ value was $<0.05$.

\section{Results}

All ten patients included in the study had chronic foot wound infections. The mean age of this group of patients were 64.4 years and the range was between 54 and 80 years. Male:female ratio was 1:1.

\section{Quality of DNA extracted each DNA extractions method}

The differences between the protocols of the six DNA extraction techniques are described in Table 1. The yield, purity and quality of the genomic DNA obtained using the six DNA extraction methods from ten specimens are given in Table 2. The lower A260/280 ratio seen in DNA extracted from some methods may indicate the presence of protein, phenol, salts or other contaminants.

Table 1 Comparison of six different DNA extraction methods examined in this study

\begin{tabular}{|c|c|c|c|c|c|c|}
\hline Extraction steps & $\mathrm{BP}_{1}$ & $\mathrm{BP}_{2}$ & $\mathrm{~K}$ & $\mathrm{H}_{1}$ & $\mathrm{H}_{2}$ & $\mathrm{~S}$ \\
\hline Lysis buffer/agent & STES buffer & TN150 buffer & $\begin{array}{l}\text { Tissue lysis buffer } \\
\text { and protinase } \mathrm{K}\end{array}$ & Distilled water & Aqueous $\mathrm{NaOH}$ & $\begin{array}{l}\text { TNES buffer and } \\
\text { protinase } \mathrm{K}\end{array}$ \\
\hline $\begin{array}{l}\text { Cell lysis and homog- } \\
\text { enization }\end{array}$ & Bead beating & Bead beating & $\begin{array}{l}\text { Incubation at } 56^{\circ} \mathrm{C} \\
\text { and vortexing }\end{array}$ & Boiling & Boiling & $\begin{array}{c}\text { Incubation at } 56^{\circ} \mathrm{C} \\
\text { and vortexing }\end{array}$ \\
\hline $\begin{array}{l}\text { Extraction and DNA } \\
\text { precipitation }\end{array}$ & $\begin{array}{l}\text { Phenol chloroform } \\
\text { and cold absolute } \\
\text { ethanol }\end{array}$ & $\begin{array}{l}\text { Phenol chloroform } \\
\text { and cold absolute } \\
\text { ethanol }\end{array}$ & $\begin{array}{l}\text { Mini column and } \\
\text { washing buffer }\end{array}$ & Heat & Heat & $\begin{array}{l}\text { Hypertonic } \mathrm{NaCl} \\
\text { and cold absolute } \\
\text { ethanol }\end{array}$ \\
\hline Store in & TE buffer & TE buffer & Elution buffer & Distilled water & Aqueous $\mathrm{NaOH}$ & TE buffer \\
\hline $\begin{array}{l}\text { Approximate time for } \\
\text { completion }\end{array}$ & $71 / 2 h$ & $8 \mathrm{~h}$ & $3 \mathrm{~h}$ & $25 \mathrm{~min}$ & $35 \mathrm{~min}$ & $11 \mathrm{~h}$ \\
\hline
\end{tabular}

$B P_{1}$ Bead beater phenol chloroform with STES buffer, $B P_{2}$ Bead beater phenol chloroform with TN150 buffer, $K$ DNeasy blood and tissue kit, $H_{1}$ Heat treating in distilled water, $\mathrm{H}_{2}$ Heat treating in $\mathrm{NaOH}$, S Salting out method 


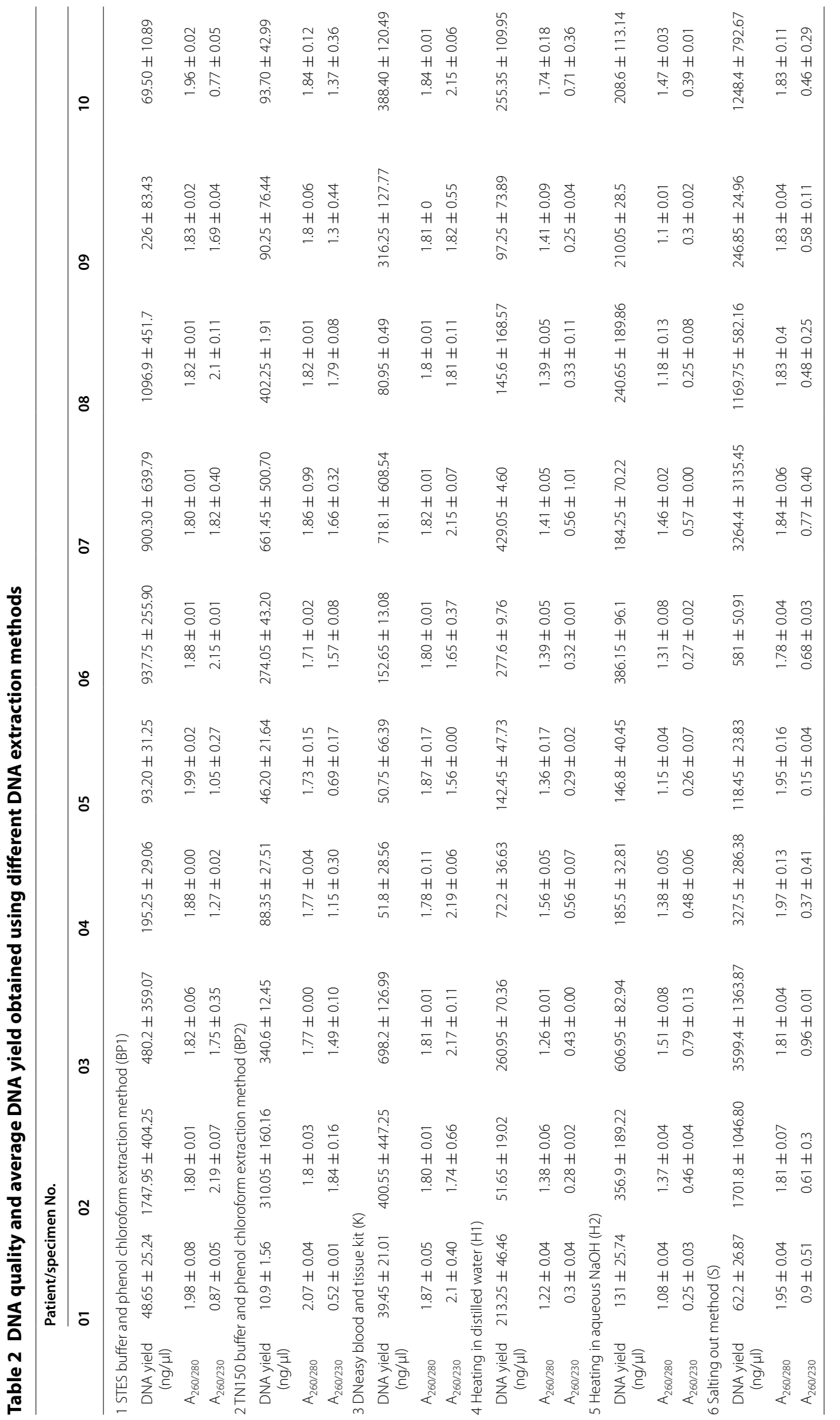


Evaluation of DNA integrity by agarose gel electrophoresis The integrity of extracted DNA samples was analyzed by agarose gel electrophoresis. A high molecular weight band indicated the presence of genomic DNA (Fig. 1). All six DNA extraction methods showed low intense bands on agarose gel (Fig. 1). However variation in the yield and purity of DNA were observed among different methods.

When the bead beater-phenol chloroform extraction methods were occupied (BP1 and BP2 method) BP1 method yielded maximum DNA yield and high A260/280 nm ratios (1.8-2.0) in each specimen. Of the ten specimens, only four yielded A260/280 nm ratios $>1.8$. Comparatively to BP1 method, BP2 method yielded low DNA amount with a little contamination by the respective substances.

The two heating methods including $\mathrm{H} 1$ and $\mathrm{H} 2$ yielded considerable amount of DNA with more contamination of proteins and other impurities. DNA extraction using $S$ method could yield maximum amount of DNA from most of the specimens but, their purity was very low. The reason for the lower DNA purity may be due to possible high salt contamination. DNA extraction using K method yielded considerably high DNA yield with a maximum A260/280 and A260/230 ratios indicating minimal DNA contaminants.

Following the Welch statistics, the extraction methods which have significant differences between the mean values of their DNA yield were grouped and multiple comparison was done using the Games-Howell. According to the multiple comparison, it was found that there was not a significant difference (at 95\% confident level) between the means of DNA yield produced by each method. However, it was found that there was a significant difference (at 95\% confident level) between the means of A260/280 ratio $(\mathrm{p}=0.000)$ : $\mathrm{BP} 1$ method and $\mathrm{H} 1, \mathrm{H} 2$ methods, $\mathrm{BP} 2$ and $\mathrm{H} 1, \mathrm{H} 2$ methods; $\mathrm{H} 2$ and $\mathrm{K}$ methods; $\mathrm{S}$ and $\mathrm{H} 1, \mathrm{H} 2$ methods. Further, a significant difference (at 95\% confident level) was found between the means of A260/230 ratios $(\mathrm{p}=0.000)$ : $\mathrm{BP} 1$ method and $\mathrm{H} 1, \mathrm{H} 2, \mathrm{~S}$ methods; BP2 method and H1, H2, S, K methods; K method and $\mathrm{H} 1, \mathrm{H} 2$, S methods.

\section{PCR amplification of V2-V3 region of $16 \mathrm{~S}$ rDNA}

In order to evaluate the effect of DNA extraction method on the quality of DNA, the DNA extracted from all six methods were used for the determination of the microbial biodiversity in wound specimens. PCR amplification of the V2-V3 region of extracted bacterial 16S rRNA gene was carried out and the products were run on agarose gel (Fig. 2). The agarose gel electrophoresis of PCR product showed well separated and consistent bands with no impurity bands, with a product size of approximately $200 \mathrm{bp}$ indicating the presence of well amplified V2-V3 region of 16S rRNA gene of bacterial species (Anukam and Reid 2007; Oates et al. 2012; Walter et al. 2001).

\section{Comparative analysis of DGGE fingerprint profiles}

Highly diverse DGGE banding patterns were observed in each specimen on $30-55 \%$ denaturing gradient. Further intra- and inter-subject variations were readily observed in the specimens following different extraction methods (Figs. 3, 4). The differences in DGGE profiles were reflected by the number and intensity of the DNA bands in comparisons of bacterial profiles of the same sample using different DNA extraction methods (Figs. 3, 4). Each DGGE band was assumed to represent a single species (Muyzer et al. 1999). Therefore, the number of bands from each lane was counted and average number of bands per specimen was calculated (Table 3).

The observed multiple bands in the DGGE gel are suggestive of a polymicrobial nature of the chronic wound infection. Theoretically, all profiles should have been identical since DNA was extracted from the tissues obtained from same chronic wound specimen. However, there was a variation in intensity of bands and number of the bands in the same specimens which were subjected for different DNA extraction methods. This observation suggests that the different DNA extraction methods may have had varying sensitivity for the different bacteria.

\section{Excising of selected DGGE bands, PCR amplification, and sequencing}

Selected predominant DGGE bands from the DGGE gel were excised, PCR amplified, purified and sequenced using Sanger method. According to the sequencing results, Enterococcus feacalis, Group A Streptococcus spp., Providencia spp., E.coli and Vellionella spp. were found in the sample no. 1 following six extraction methods (Fig. 1). However the resulting intensity of these DGGE bands differed in different extraction methods. Pseudomonas aeruginosa was found from six extraction methods done for specimen No. 2 (Fig. 2). When considering the specimen No. 2, Providencia spp. could only be identified from the BP1 method while other methods did not yield the specific DNA band (Fig. 2).

\section{Discussion}

Among the five tested conventional methods, bead beater/phenol-chloroform based DNA extraction method with STES buffer (BP1 method) gave a yield of DNA with high purity. Further it resulted in broad diversity of bacterial communities in chronic wounds using PCR-DGGE. This method is a less time consuming process and less expensive, therefore it can be easily applied for the settings where expediency and cost effectiveness is essential. This reinforces the BP1 method as an 

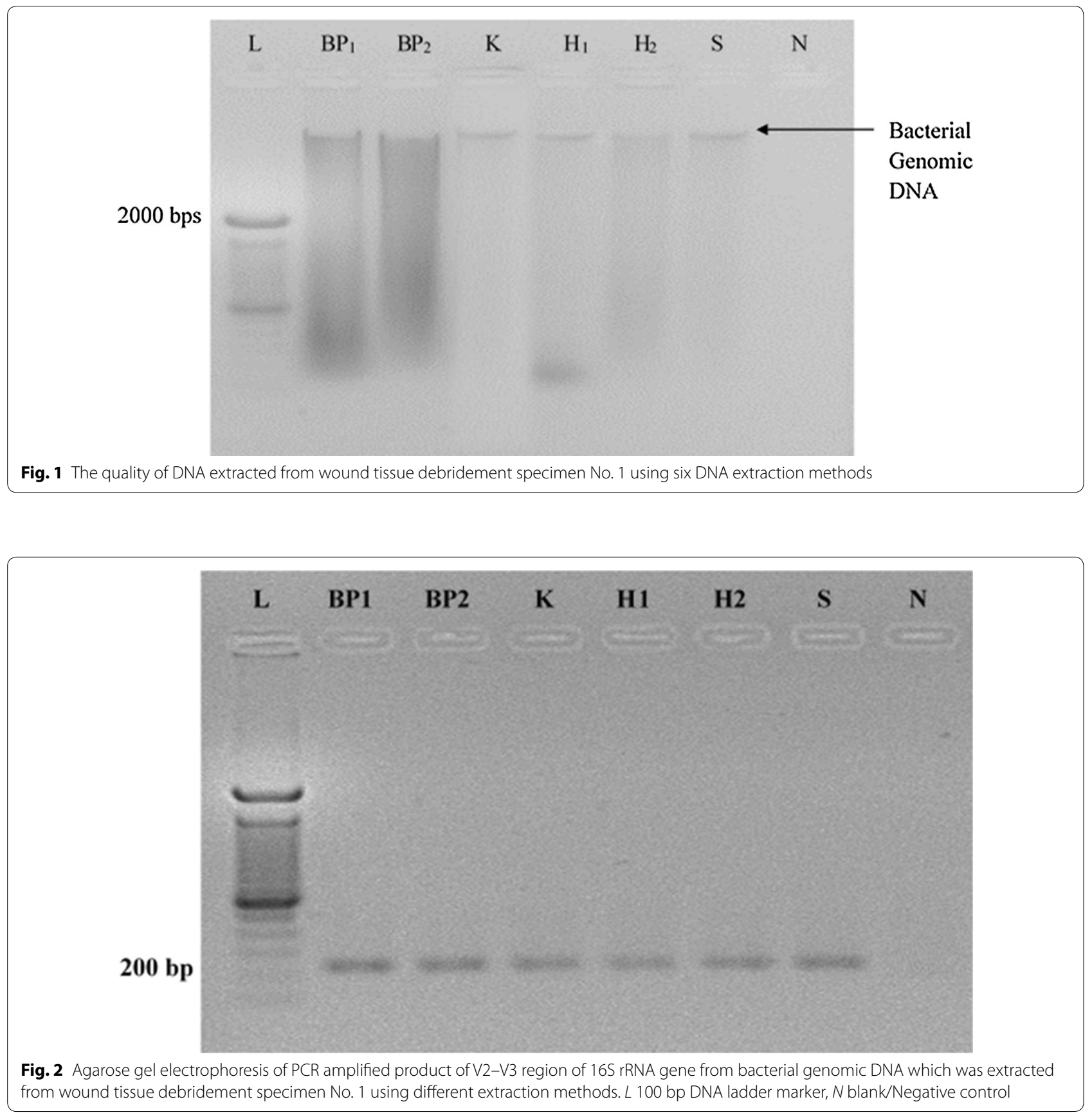

appropriate, conventional DNA extraction method to study microbial communities in human chronic wounds. The DNeasy Blood and Tissue Kit (K method) produced good quality genomic DNA with appreciably greater yield compared to the quality and yield of the other five conventional DNA extraction methods. Further K method gave a broad diversity of bacterial communities in chronic wounds using PCR-DGGE.

Isolation of genomic DNA is a multi-step procedure including cell disruption, DNA extraction and
DNA recovery. Bacterial cell lysis is a critical step in the extraction process. The extracted DNA should be free of contaminants including the least amount of proteins, carbohydrate, lipids, other nucleic acid (RNA), other cellular constituents that may interfere with restriction enzymes, ligase and thermostable DNA polymerases or any other PCR inhibitors (Asadzaheh et al. 2010). Removing contaminants is one important key factor for a successful PCR, since quality and integrity of the isolated DNA will directly affect the results of all succeeding procedures. 


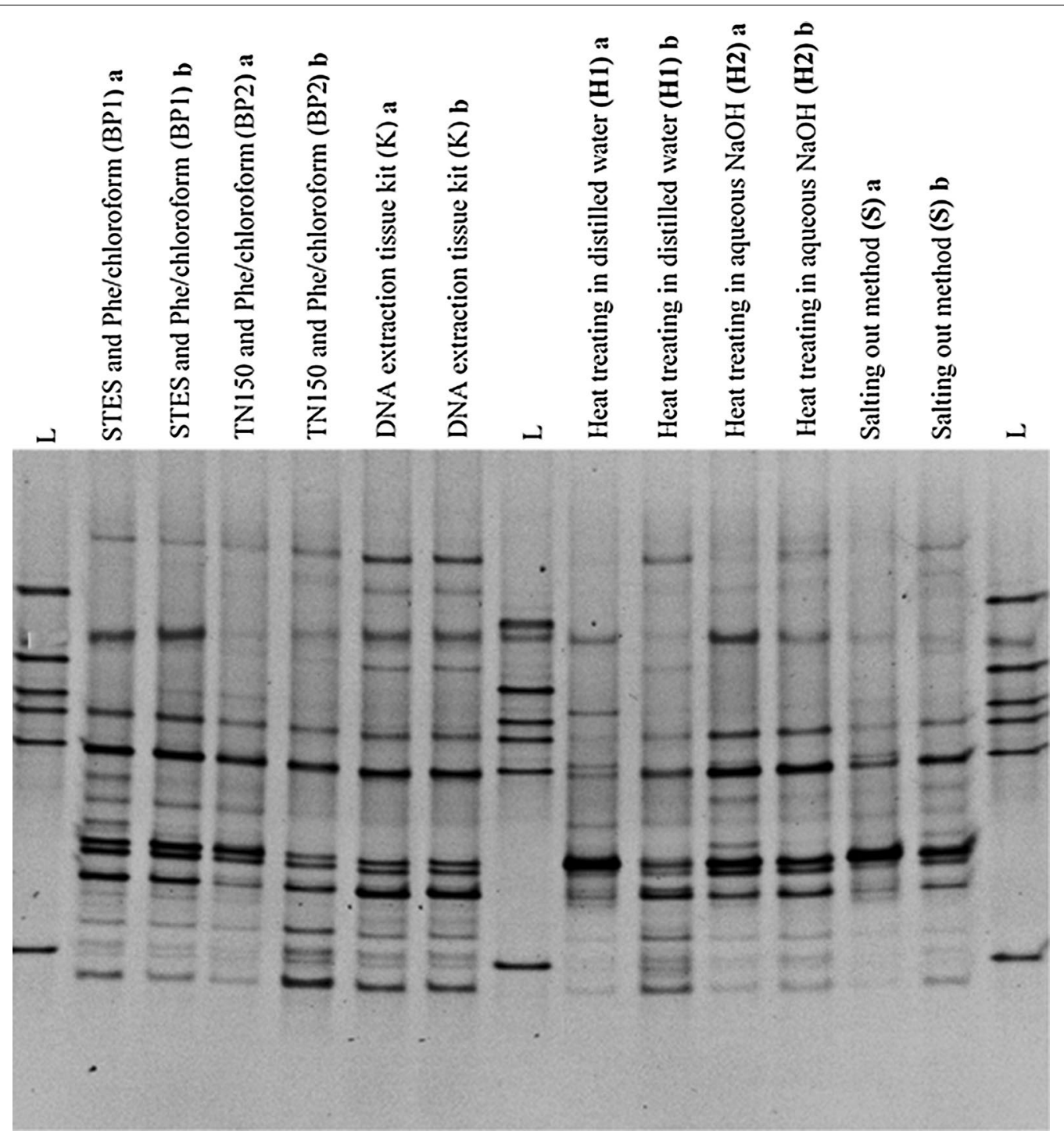

Fig. 3 A comparison of DGGE profiles of PCR amplified bacterial 16S rRNA gene for the specimen No: 1. DNA was extracted using six different DNA extraction methods using $25 \mathrm{mg}$ of wound tissue debridement specimen no. 1. Bacterial fingerprinting profile is based on 30-55\% denaturing gradient. "L" lanes represent the in house bacterial reference panel which includes S. aureus, Acinetobacter spp, Group B Streptococcus spp., E. faecalis, Group A Streptococcus spp. and E. coli from top to bottom respectively. Other lanes show bacterial fingerprinting profile of each extraction method in duplicate $(a, b)$ for the specimen No. 1, collected from a subject with a chronic wound

Absorbance of DNA was measured at $260 \mathrm{~nm}$ to evaluate the quantity of the extracted DNA, and the ratio of A260/280 nm was used to evaluate the DNA purity. The A260/230 nm ratio is used as a secondary measure of nucleic acid purity. The A260/230 values for "pure" nucleic acid are often higher than the respective A260/280 values. Commonly expected A260/230 ratio should be greater than 1.8. If the ratio is appreciably lower than expected, it may indicate the presence of contaminants which absorb at $230 \mathrm{~nm}$ such as TE buffer.

Small changes in the $\mathrm{pH}$ of the DNA solution can cause variations in A260/280 ratio (Wilfinger et al. 1997). The
A260/280 ratio will be under-represented and over-represented by $0.2-0.3$, when DNA are in acidic solutions and basic solutions respectively.

Commonly used DNA extraction procedures employ a buffer containing one or several detergents such as SDS, NP-40, Triton X-100 or CTAB which aids cell lysis and the removal of proteins from DNA (Moore and Dowhan 1995). Both STES and TNES buffers used for the DNA extraction in our study (BP1 and S methods) contains SDS. Excessive SDS above 0.01\% may inhibit the PCR by denaturing Taq polymerase (Yang 2008). Therefore, extracted DNA had to be diluted 1:10 with PCR water 


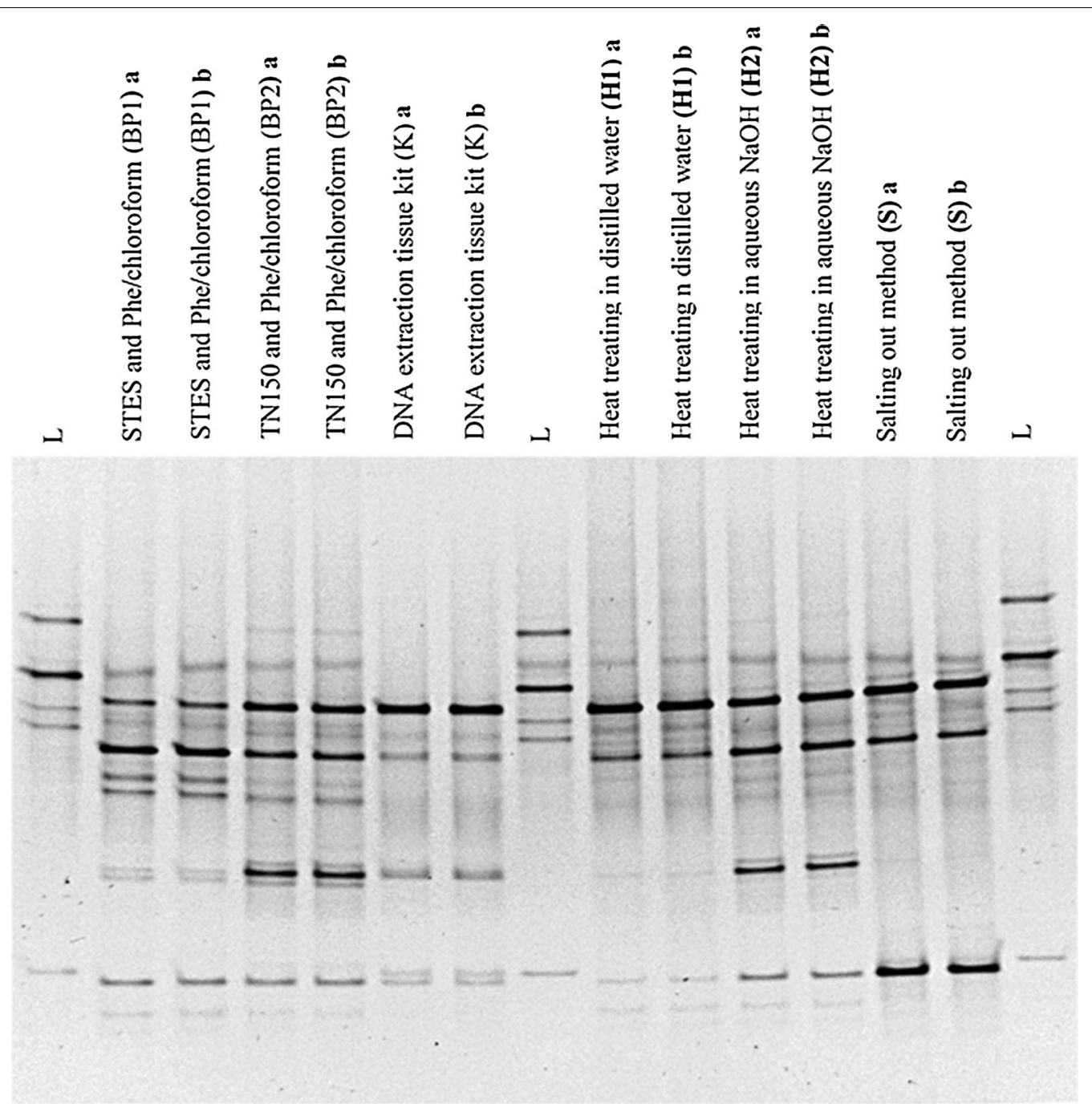

Fig. 4 A comparison of DGGE profiles of PCR amplified bacterial 16S rRNA gene for the specimen No: 2. DNA was extracted using six different DNA extraction methods. Bacterial fingerprinting profile was based on 30-55\% denaturing gradient. "L" lanes represent the in house bacterial reference panel which includes S. aureus, Acinetobacter spp., Group B Streptococcus spp., E. faecalis, and E. coli from top to bottom respectively. Other lanes show bacterial fingerprinting profile of each extraction method in duplicate $(a, b)$ for the specimen No. 2, collected from a subject with a chronic wound

Table 3 Determination of microbial diversity of six different extraction methods using DGGE

\begin{tabular}{|c|c|c|c|c|c|c|c|c|c|c|}
\hline \multirow[t]{2}{*}{ DNA extraction method } & \multicolumn{10}{|c|}{ Average number of bands in each specimen } \\
\hline & S/no: 1 & 2 & 3 & 4 & 5 & 6 & 7 & 8 & 9 & 10 \\
\hline STES buffer and phenol chloroform extraction method (BP1) & 14 & 10 & 06 & 08 & 16 & 11 & 06 & 04 & 04 & 08 \\
\hline TN150 buffer and phenol chloroform extraction method (BP2) & 14 & 12 & 07 & 09 & 13 & 12 & 07 & 05 & 08 & 09 \\
\hline DNA extraction tissue kit (K) & 15 & 06 & 07 & 10 & 11 & 13 & 07 & 04 & 05 & 06 \\
\hline Boiling in distilled water $(\mathrm{H} 1)$ & 13 & 09 & 05 & 08 & 06 & 08 & 05 & 05 & 08 & 05 \\
\hline Boiling in aqueous $\mathrm{NaOH}(\mathrm{H} 2)$ & 14 & 11 & 06 & 11 & 10 & 12 & 07 & 06 & 08 & 07 \\
\hline Salting out method (S) & 14 & 09 & 05 & 07 & 10 & 12 & 05 & 05 & 08 & 06 \\
\hline
\end{tabular}

S/No specimen number 
before the PCR amplification. In our study, the DNA yield obtained from BP1 method is ranged 49-1747.95 ng/ $\mu \mathrm{l}$ and A260/280 ratios for all specimens were greater than 1.8. However A260/230 ratios for several specimens resulted less than 1.8 indicating residual carryovers such as phenol, in the extraction mixture. The DNA yield obtained by $S$ method (ranged 62-3599 $\mathrm{ng} / \mu \mathrm{l}$ ) was greater than the DNA yield obtained by other five methods. Further, A260/280 nm ratios for all specimens were similar or greater than $1.8 \mathrm{but}$ A260/230 nm ratios were always less than 1.8 indicating a high salt contamination in the extraction mixture. In the $\mathrm{S}$ method, the use of saturated $\mathrm{NaCl}$ results in protein precipitation followed by DNA precipitation by ethanol (Yang 2008). Although washing with $70 \%$ ethanol would remove the residual carryovers, presence of high salt contamination in the extraction mixture can result in a decrease in purity of DNA.

When considering phenol-chloroform based extraction methods (BP1 and BP2 methods) the DNA quantification and purity determination using UV absorbance at $260 \mathrm{~nm}$ may be error prone due to the high extinction coefficient of phenol at $260 \mathrm{~nm}$ resulting in lower detectable yields (Yang 2008). Further, the toxicity of phenol and labor-intensity should be carefully considered when phenol-chloroform based extraction methods are carried out. Therefore, this method can be further improved by using a phase lock gel as a barrier.

In the current study, BP1 method yielded good quality DNA compared to BP2 method. A lower A260/230 nm ratio may be due to phenol contamination in the extracted mixture. Under BP2 method, several specimens out of ten specimens resulted the A260/A280 nm ratio as less than 1.8 that indicates protein contamination or presence of organic contaminants, such as phenol, and other aromatic compounds.

In this study, two different heat treatment methods were followed using sterile distilled water and aqueous $\mathrm{NaOH}$. DNA is less reactive and stable in alkaline conditions. Therefore it is very important to avoid acidic conditions during DNA extraction, since depurination of DNA can occur. Therefore, DNA is usually stored at $\mathrm{pH} 8.0$ to avoid even slightly acidic conditions that may over time lead to base losses. In this study, when the extractions were done using the heating methods such as $\mathrm{H} 1$ and $\mathrm{H} 2$, both A260/A280 $\mathrm{nm}$ ratios and A260/230 $\mathrm{nm}$ ratios for all ten specimens were less than 1.8 that was indicative of ominously low purity/quality DNA due to the absence of specific DNA purification steps following cell lysis. Therefore although these two methods were extremely easy and inexpensive, the DNA purity was very poor.

In DNeasy blood and tissue kit method, de-proteinization was achieved by proteinase $\mathrm{K}$. Proteinase $\mathrm{K}$ is active in the presence of SDS and also at elevated temperature $\left(56-65{ }^{\circ} \mathrm{C}\right)$. However other enzymes such as DNases are denatured under these conditions. In our study, K method yielded good quality DNA than other five methods.

As many reports described, commercially available mini column-purification methods yield DNA of high purity containing the least amount of PCR-inhibitory substances. Oates et al. (2012), reported extraction of DNA from archived macerated chronic wound tissue samples and swab samples using DNeasy blood and tissue kit for microbial profiling using PCR-DGGE (Oates et al. 2012). This method enabled DNA extraction in less than $3 \mathrm{~h}$.

DNeasy blood and tissue kit resulted in the largest diversity of bands in PCR-DGGE followed by the BP1 method. Although the $\mathrm{H} 2$ method had the lowest purity DNA, a good band diversity was observed in DGGE gel.

In this study, the identification of the different bacterial species in each specimen was not done using PCR-DGGE. The objective was to evaluate effective DNA extraction method to profile the bacterial population in the infected chronic wounds using PCR-DGGE. The DGGE method is a qualitative and semi-quantitative method; the abundance of microorganisms can be reflected by the DGGE profile (Fan et al. 2014). The number of DGGE bands can reflect the bacterial diversity of the infected chronic wounds, and can be applied for semi-quantitative analysis using the intensity of the bands.

Each extraction method had their own pros and cons. Many variations can be found in DNA extraction methods which occur between laboratories. This may diminishes the consistency and comparability between studies. These findings suggest that the quality and yield of genomic DNA is influenced by each DNA extraction protocol.

\section{Abbreviations \\ DNA: deoxyribonucleic acid; PCR: polymerase chain reaction; DGGE: dena- turing gradient gel electrophoresis; RNA: ribonucleic acid; $\mathrm{NaOH}$ : sodium hydroxide; rDNA: ribosomal deoxyribonucleic acid; $\mathrm{HCl}$ : hydrochloric acid; EDTA: ethylenediaminetetraacetic acid; SDS: sodium dodecyl sulfate; TE: Tris- EDTA buffer solution; MgCl2: magnesium chloride; dNTP: deoxy nucleoside tri-phosphate; dATP: deoxy adenosine tri-phosphate; dGTP: deoxy guanidine tri-phosphate; dCTP: deoxy cytosine tri-phosphate; dTTP: deoxy thymidin tri- phosphate; TAE: Tris base, acetic acid and EDTA; UV: ultra violet; SPSS: statistical package of social sciences; SD: standard deviation; CTAB: cetyl trimethylam- monium bromide; $\mathrm{NaCl}$ : sodium chloride.}

\section{Authors' contributions}

AD Carried out bench work, data collection, results analysis and drafted the manuscript. AS carried out bench work, data collection and involved in manuscript preparation. MW, CG, and NF designed and guided the experiments. DW selected and recruited the patient for the study. CS provided all the equipment required for DGGE. CS and AM advised for the overall study. All engaged for writing of the manuscript. All authors read and approved the final manuscript. 


\section{Author details}

1 Department of Microbiology, Faculty of Medical Sciences, University of Sri Jayewardenepura, Gangodawila, Nugegoda, Sri Lanka. ${ }^{2}$ Department of Surgery, Faculty of Medical Sciences, University of Sri Jayewardenepura, Gangodawila, Nugegoda, Sri Lanka. ${ }^{3}$ Department of Pathology and Molecular Medicine, University Otago, Wellington, New Zealand. ${ }^{4}$ Faculty of Biology, Medicine and Health, The University of Manchester, Manchester M13 9PT, UK.

\section{Acknowledgements}

The authors wish to thank the participating patients and staff of Colombo South Teaching Hospital and Department of Microbiology, Faculty of Medical Sciences, University of Sri Jayewardenepura, Department of Community Medicine, University of Sri Jayewardenepura, Sri Lanka for their support in this study. The authors gratefully thank Mr. J. A. Munasinghe for statistical analysis.

\section{Competing interests}

The authors declare that they have no competing interests.

\section{Availability of data and materials}

The data supporting the findings of this study are included in the main manuscript file.

\section{Compliance with ethical standards}

Accepted principles of ethical and professional conduct have been followed.

\section{Consent to publish}

Consent to publish has been obtained from the participant to report individual patient data.

\section{Ethical approval and consent to participate}

Ethical approval for this study was obtained from the Ethical Review Committee of University of Sri Jayewardenepura, Sri Lanka (Ref. No: 12/16) and Colombo South Teaching Hospital, Sri Lanka (Ref. No: 506) as well as the patients' approval was obtained prior to the sample collection.

\section{Funding}

This work was supported by the University of Sri Jayewardenepura, Sri Lanka (Grant No: ASP/01/RE/MED/2015/41) and partially funded by Ministry of Health, Sri Lanka. (Grant No: 2015/67).

\section{Publisher's Note}

Springer Nature remains neutral with regard to jurisdictional claims in published maps and institutional affiliations.

Received: 22 June 2017 Accepted: 5 September 2017 Published online: 19 September 2017

\section{References}

Anukam K, Reid G (2007) Organisms associated with bacterial vaginosis in Nigerian women as determined by PCR-DGGE and 16S rRNA gene sequence. Afr Health Sci 7(2):68-72

Ariefdjohan MW, Savaiano DA, Nakatsu CH (2010) Comparison of DNA extraction kits for PCR-DGGE analysis of human intestinal microbial communities from fecal specimens. Nutr J 9:23. doi:10.1186/1475-2891-9-23

Asadzaheh N, Javanmard A, Nassiry MR (2010) Comparison of rapid DNA extraction techniques for conventional PCR-RFLP analysis from mammalian whole blood cells. J Mol Genet 2(3):32-35

De Lipthay JR, Enzinger C, Johnsen K, Aamand J, Sørensen SJ (2004) Impact of DNA extraction method on bacterial community composition measured by denaturing gradient gel electrophoresis. Soil Biol Biochem 36(10):1607-1614. doi:10.1016/.j.soilbio.2004.03.011

Fan W, Li X, Yang L, Huo G (2014) Comparison of DNA extraction methods for polymerase chain reaction-denaturing gradient gel electrophoresis (PCRDGGE) analysis of the infant fecal microbial communities. Afr J Microbiol Res 8(9):908-914
Han A, Zenilman JM, Melendez JH, Shirtliff ME, Agostinho A, James GA, Stewart PS, Mongodin EF, Rao D, Rickard AH (2011) The importance of a multifaceted approach to characterizing the microbial flora of chronic wounds. Wound Repair Regen 19(5):532-541

McOrist AL, Jackson M, Bird AR (2002) A comparison of five methods for extraction of bacterial DNA from human faecal samples. J Microbiol Methods 50(2):131-139

Moore DD, Dowhan D (1995) Preparation and analysis of DNA. Curr Protoc Mol Biol 58(2.0):2.0. 1-2.0. 3

Moore E, Arnscheidt A, KrÜger A, StrÖmpl C, Mau M (2008) Section 1 update: simplified protocols for the preparation of genomic DNA from bacterial cultures molecular microbial ecology manual. Springer, Netherlands, pp 1905-1919

Muyzer G, De Waal EC, Uitterlinden AG (1993) Profiling of complex microbial populations by denaturing gradient gel electrophoresis analysis of polymerase chain reaction-amplified genes coding for 165 rRNA. Appl Environ Microbiol 59(3):695-700

Nakatsu CH (2007) Soil microbial community analysis using denaturing gradient gel electrophoresis. Soil Sci Soc Am J 71(2):562-571

Oates A, Bowling FL, Boulton AJ, McBain AJ (2012) Molecular and culturebased assessment of the microbial diversity of diabetic chronic foot wounds and contralateral skin sites. J Clin Microbiol 50(7):2263-2271. doi:10.1128/JCM.06599-11

Øvreås L, Forney L, Daae FL, Torsvik V (1997) Distribution of bacterioplankton in meromictic Lake Saelenvannet, as determined by denaturing gradient gel electrophoresis of PCR-amplified gene fragments coding for $16 \mathrm{~S}$ rRNA. Appl Environ Microbiol 63(9):3367-3373

Rasiah IA, Wong L, Anderson SA, Sissons CH (2005) Variation in bacterial DGGE patterns from human saliva: over time, between individuals and in corresponding dental plaque microcosms. Arch Oral Biol 50(9):779-787

Sampath A, Weerasekera M, Gunasekara C, Dilhari A, Bulugahapitiya U, Fernando N (2016) A sensitive and a rapid multiplex polymerase chain reaction for the identification of Candida species in concentrated oral rinse specimens in patients with diabetes. Acta Odontol Scand 75(2):113-122. doi:10.1080/00016357.2016.1265146

Silva GAD, Bernardi TL, Schaker PDC, Menegotto MM, Valente P (2012) Rapid yeast DNA extraction by boiling and freeze-thawing without using chemical reagents and DNA purification. Braz Arch Biol Technol 55:319-327

Tannock G (2002) Analysis of the intestinal microflora using molecular methods. Eur J Clin Nutr 56:S44-S49

Vesty A, Biswas K, Taylor MW, Gear K, Douglas RG (2017) Evaluating the impact of DNA extraction method on the representation of human oral bacterial and fungal communities. PLoS ONE 12(1):e0169877

Wadinamby JMRWW (2013) Chronic wounds and their management and application in a contemporary Sri Lankan hospital setting. SLJID 3(2):2-16. doi:10.4038/sljid.v3i2.5974

Walter J, Hertel C, Tannock GW, Lis CM, Munro K, Hammes WP (2001) Detection of Lactobacillus, Pediococcus, Leuconostoc, and Weissella species in human feces by using group-specific PCR primers and denaturing gradient gel electrophoresis. Appl Environ Microbiol 67(6):2578-2585. doi:10.1128/AEM.67.6.2578-2585.2001

Weerasekera MM, Sissons CH, Wong L, Anderson S, Holmes AR, Cannon RD (2013) Use of denaturing gradient gel electrophoresis for the identification of mixed oral yeasts in human saliva. J Med Microbiol 62(Pt 2):319-330. doi:10.1099/jmm.0.050237-0

Weerasekera M, Sissons CH, Wong L, Anderson S, Holmes AR, Cannon RD (2017) Denaturant gradient gel electrophoresis profiles of bacteria from the saliva of twenty four different individuals form clusters that showed no relationship to the yeasts present. Arch Oral Biol 82(2):6-10

Wilfinger WW, Mackey K, Chomczynski P (1997) Effect of pH and ionic strength on the spectrophotometric assessment of nucleic acid purity. Biotechniques 22(3):474-476

Yang JL (2008) A simple and rapid method for extracting bacterial DNA from intestinal microflora for ERIC-PCR detection. World J Gastroenterol 14(18):2872. doi:10.3748/wjg.14.2872 